\title{
Old Traditions, New Practices: A Proposal for a Return to Text Study as a Centerpiece of Jewish Community and Family Life
}

Daniel P. Resnick and Lauren B. Resnick

\begin{abstract}
Thile study of classical Jewish texts has always been central to the traditional curriculum, that study has waxed and waned among liberal Jews. In this chapter, Daniel and Lauren Resnick offer their own critical survey of that phenomenon. In particular, they hypothesize that the status of classical text study waned in part due to the erosion of the educational norm of textual discussion in general education. In other words, as information-delivery models came to dominate pedagogy in schools-as textbooks crowded out texts-Jewish education followed suit. However, they suggest that the tide has turned in the last decades, with a wave of research in general education that focuses on "dialogic instruction" and that emphasizes participatory discussion of texts. Texts, then, are making a comeback against textbooks, and the prospects for Jewish education are positive.
\end{abstract}

\section{Introduction}

The period of post-Holocaust life in America is unlike any known before in the history of the Jewish diaspora. Jews are actively engaged in every phase of American life and are widely respected in their professional and social lives. The great majority of non-orthodox American Jews-Reform, Conservative, and Reconstructionist-marry freely with partners of other faiths and often create new kinds of Jewish families in the process. And yet, we are different, and many of us seek to maintain that difference. 
A major distinction between Jews and those of other faiths has been our relationship to sacred texts. Iconic representations of the Ten Commandments on tablets adorn our places of worship, the ark containing Torah scrolls occupies center stage in our synagogues, our doorposts are hung with rolled-up pieces of parchment from Deuteronomy, calling on us to harken to our past, remember our commandments, and educate our children. All of these are symbols of the centrality of Torah to Judaism and the Jewish community.

Jewish identity and survival as a people have been intimately connected with the study of texts: Torah, its many layers of commentary, and other classical Jewish texts. We have historically been a "people of the book" with high literacy rates and curiosity about words, stories, and meaning, although the "book" in question has never only been the Pentateuch or even the entire Hebrew Bible. ${ }^{1}$ Through encounters with a variety of Jewish sacred texts, we engage in a process of dialogue with the past that affirms our membership in the stream of Jewish experience. Community study of sacred texts has lent Judaism in the diaspora dignity and depth, distinguishing it in positive and self-sustaining ways from the surrounding Christian and Muslim communities.

Most of today's American Jewish community, however, seems to have lost its connection to traditional text study. The bond between Jewish identity and text study is strongest for the orthodox, and weaker among Conservative, Reform, and other denominations. Notwithstanding the "back to the sources" movement beginning in the 1980s, community surveys indicate that no more than one quarter of all adults who identify as Jewish take part in "structured Jewish learning activities." These can include going to a class, attending a lecture, or discussing a text. ${ }^{2}$ When a more specific question is posed about how important text study itself is to "being Jewish," the portion affirming its importance is even smaller. Lisa Grant, a prominent evaluator of adult Jewish learning concludes: “... it appears that formal study just is not a high priority

1 Barry Holtz has made the case strongly and clearly: "Torah and its study is the dominant religious preoccupation throughout the history of Judaism. ..." See Barry Holtz, ed., Back to The Sources: Reading the Classic Jewish Texts (New York: Summit Books, 1984), 12. For Amos $\mathrm{Oz}$ and his daughter Fania, "Ours is not a bloodline but a textline." See Amos Oz and Fania Oz-Salzberger, Jews and Words (New Haven, CT: Yale University Press, 2012), 1.

2 According to Laurence Kotler-Berkowitz et al., "National Jewish Population Survey (NJPS) 2000-2001," "Among all adults in the more strongly connected Jewish population, 24 percent (just over 800,000 total people) attended an adult Jewish education class or other kind of adult Jewish learning. . .." See http://www.jewishdatabank.org/studies/details.cfm?StudyID=307. Neither the 2000-2001 NJPS nor the Pew Study of 2013 pose questions about regular text study as a Jewish practice. 
among most American Jews." 3 In its fullest and deepest form, Jewish text study is a lengthy process with no shortcuts; it calls for more time than families with busy schedules now think they can afford. And what place could it have, some will say, in a society concerned with digests, visuals, key words, and the "bottom line?"

In this essay we remain optimistic, nonetheless, that text study will remain a central part of Jewish learning and community participation, and we are even optimistic that its appeal to adults and families within the liberal Jewish community can grow. We confirm the persistence of Torah study with modern study aids in the liberal community, and argue that traditional types of analysis, argument, and discussion can be applied to a variety of new "texts." Jews in America have become engaged with short stories, novels, histories, and poetry along with theater, serious journalism, and film. Liberal Jews may not be spending enough time with the traditional body of Torah writings and commentary, but they have been engaged with many other kinds of texts that illuminate the story of the Jewish people.

Beyond these points, however, we also want to pursue an argument based on developments in the theory and practice of text study within secular educational contexts. We are encouraged by these developments, which are making a larger place for discussion, listening, and responding to texts of many different kinds. We believe that these developments can help make text-based discussion and argument part of the curriculum of Reform and Conservative educational programs. Efforts in this direction have already begun.

In our first section below we offer a brief perspective on the evolution of discussion and argument in the study of our traditional Jewish texts, particular in liberal Jewish communities. We want to offer a view of the landscape, calling

3 See Lisa Grant, "Jewish Men and Adult Jewish Learning," 5. Accessed in the Berman Jewish Policy Archive, https://www.bjpa.org/search-results/publication/4803 [Originally published in The Gender Gap (New York: URJ Press 2007)]. Grant reports that In a Long Island survey, only 13 percent to 18 percent assigned high priority to text study as a practice, with significant gender differences among Reform and Conservative respondents. "Simply put, it appears that women act on being Jewish more than men." When a question is asked about "Jewish study," without specification of texts as such, the portion responding positively is higher, but does not rise above 25 percent. The denominational differences are confirmed in the Pittsburgh Jewish Community Study, 2002. When asked in a telephone survey whether they had been "regularly engaged" in Jewish study during the preceding year or two, 25 percent of the Conservatives said "yes," as did 19 percent of the Reform, 56 percent of the orthodox, and 8 percent of the others. This survey did not seek out differences in the practices of men and women. See Ukeles Associates, "The 2002 Pittsburgh Jewish Community Study Final Report" (updated December 2002): 86, http://www.jfedpgh.org/document.doc?id=13. 
attention to certain features that we believe are significant. In the second section, we consider the changes that are taking place in the education of children, where social theory and theories of language and learning are changing school practice. In the third section, we call attention to the ways that the new focus on textual engagement in mainstream American education echoes and adapts traditional Jewish approaches to text, as well as propose some new ways that it might do so. Finally, we conclude by expressing optimism about the future of Jewish text exploration and its contribution to the cultural life of our people.

\section{The Evolution of Jewish Text Study in Non-Orthodox Settings}

Despite the relatively few people participating in it, few practices have evolved in style and focus in the non-orthodox community as much as text study. A variety of tools have emerged to support the study of texts in multiple venues. Outside of a small scholarly community, most Jews in America are unable to read and understand the sacred texts in the language in which they were written. However, side-by-side Hebrew/English pages of the Pentateuch, with notes and commentary, now allow American Jews to approach the printed word closely and critically. A variety of online study aids have also come into widespread use. The impact of these tools, providing access to those without traditional training, cannot be underestimated.

The habits of study, interpretation, and discussion have persisted and are now in evidence as Jews engage with a variety of texts in many languages and many disciplines. These habits of mind were shaped in Torah study. As Ismar Schorsch wrote in his foreword to Etz Hayim: Torah and Commentary, the important Hebrew-English volume of annotated Torah text and commentaries from the Conservative movement:

Judaism is above all a life of dialogue. Revelation destined Israel to become a nation of readers and interpreters. ... Jews learned to read deeply rather than quickly, disjunctively as well as contextually. Each generation and every Jew was bidden to pore over the text afresh to internalize its normative force and to garner another layer of undetected meaning. ${ }^{4}$

While the Jewish interpretive tradition has always been diverse, nonscholarly readers now have more than one pair of eyes to read the text.

4 Ismar Schorsch, forward to Etz Hayim: Torah and Commentary, ed. David L. Lieber (Philadelphia: Jewish Publication Society, 2001), xvii. 
Translators' notes and observations about historical context appear below the line and in appended essays. Literary theory, moreover, has changed the very definition of a text, obliging the reader to engage with it to give it meaning. Women's authority to interpret text has challenged what had been a male monopoly, increasing empathy for Biblical characters and heightening appreciation for human agency.

\section{The Bar/Bat Mitzvah}

To take one prominent context as an example, text study for the Bar/Bat Mitzvah has benefited from these developments by providing young students with a wealth of approaches and interpretive stances that, just a few decades ago, would not have been available. Much has been written about the social side of celebrating this rite of passage, and many jokes made about the gift-giving associated with it. But in liberal Jewish communities, the heart of the Bar/ Bat Mitzvah is study of the Torah. Preparation for the ceremony of Bar/Bat Mitzvah begins with the traditional patterns of Torah study. The young person will carefully examine the portion of the week for the Saturday on which the ceremony will be held, usually with a rabbi or educator from the congregation. After studying the text, with notes and commentary, the boy or girl has two tasks. The first is to read from the Torah scroll and the second is to prepare a talk to the congregation - a d'var Torah — on the meaning of the text. To make this "coming of age" ceremony possible, many members of the congregation contribute their knowledge and skills, and family members who come before the opened Torah scroll rehearse their Hebrew to offer their blessings. But of equal importance, the effort to articulate some meaningful perspective on the text depends on a set of new intellectual resources that are readily available. To be sure, in many cases the social elements seem to displace the religious and intellectual ones. Nevertheless, the ceremony is a validation of the role played by Torah study in maintaining Jewish identity across generations, even as the d'var Torah is frequently a fascinating example of how to read old texts in new ways.

Looking beyond the Bar/Bat Mitzvah, we can see evolving modalities of text study that help Jews - particularly adults — to keep text study vibrant. What follow are some other examples drawn from our experiences and observations of contexts of text study that seem to draw increasing, and increasingly diverse, numbers of participants. 


\section{Tikkun Leil Shavuot/Shavuot Eve Study}

Every Sabbath is a special day for Torah study, but one holiday marks the central experience of receiving the Torah, the holiday of Shavuot. In many Jewish communities across America, the evening of Shavuot has become an occasion for late night Jewish learning, on a community-wide as well as a congregational basis, adapting the kabbalah-influenced practice of an all-night study session (or "tikkun"). 5 The diversity of backgrounds of attendees at such events offers evidence that a traditional observance can extend its reach to nonorthodox members of the community. Many denominations can recognize what they have in common, and that text study, short lectures by the learned, and Jewish argument can have a continuing appeal. Moreover, the texts studied at a Shavuot Eve Study may range broadly, from Torah and Talmud, to medieval philosophy, to modern poetry. In this way, Shavuot Eve Study has become, in some locations, a kind of mini-festival of Jewish culture.

\section{Weekly and Daily Study}

At the congregational level, Jewish text learning through rabbi-led study of the weekly portion, often before Saturday morning services, and rabbi-led Talmud courses appear to be growing significantly, although still drawing only a small committed core. In addition, in large cities, there is a growth in lay-led minyanim, some of which meet separately for text study. Doctors and lawyers, within their own professional groups, sometimes meet to study text, often focused on medical and legal ethics. Jewish agencies may sponsor some of this activity, but it is often grassroots and bottom-up. Some of those who participate in Torah study prepare in advance by consulting the many online commentaries readily available to them.

The Conservative and Reform movements have both produced volumes that include not only the Torah and its translation but also aids for study. The Conservative Etz Haim includes 160 pages of essays that reflect the movement's

5 Community-wide Shavuot observances in many American cities are posted on the Internet and organized at the local level. For some reporting on how this has proceeded in a middle-sized city like Pittsburgh, see Toby Tabachnick, "Community Shabbaton Will Cross Denominational Lines," The Pittsburgh Jewish Chronicle, April 25, 2012, and Andrew Goldstein, "Jewish Pittsburgh Studies All Night and into the Morning to Mark Shavuot," The Pittsburgh Jewish Chronicle, June 3, 2012, http://www.thejewishchronicle.net/view/ full_story/18843574/article-Jewish-Pittsburgh-studies-all-night-and-into-the-morning-tomark-Shavuot. 
effort to absorb critical biblical scholarship without challenging the divinely inspired character of the work. The discussion of Revelation, Torah, and Mt. Sinai in the essays by Daniel Gordis and Elliot Dorff illustrates this well. ${ }^{6}$ In the Reform movement, David Stein's The Torah: A Modern Commentary, an updating of Gunther Plaut's earlier work, ${ }^{7}$ and Tamara Cohn-Eskenazi's The Torah, A Women's Commentary ${ }^{8}$ likewise provide tools for study along with the text.

Since the 1980s, Federations, denominations and Congregations have mounted educational programs for adults, children, and families. Formal text study has many sponsors and is available in many formats. Me'ah programs developed by Hebrew College in the 1990s are now getting support from the Combined Jewish Philanthropies of Greater Boston and are being reconceived for different demographics. The Florence Melton Adult Jewish Mini-School program developed at the Hebrew University of Jerusalem now offers courses, according to its website, to 5,500 adults in almost fifty sites.

Beyond the weekly rhythm of classes, there is also a pattern of daily study, known as Daf Yomi, literally, "the daily page." The page in question refers to a page of Talmud, and the Daf Yomi curriculum is a standardized schedule of daily Talmud study that was formalized almost a century ago. But now it is supported on the web, with English-language translations and websites dedicated to the practice, making it accessible far beyond its core audience of orthodox men.

We note that Chancellor Arnold Eisen of the Jewish Theological Seminary, in a Wall Street Journal op-ed, called for renewing and revising the practice. He did not critique Talmud study, but said that we need "a different page of Jewish learning, one that is open to the larger world and bears the impact of modern thinking." That "different page" would be both traditional and modern. "It would cleave faithfully to texts, rituals, history and faith while being informed by art, music, drama, poetry, politics and law." But crucially, Eisen's vision maintained the daily rhythm of Daf Yomi. "Imagine if every Jew who wished to do so

6 David L. Lieber, ed., Etz Hayim: Torah and Commentary (Philadelphia: Jewish Publication Society, 2001). See Hillel Halkin's nuanced and sometimes grudging assessment of this achievement in Hillel Halkin, "Boiling a Kid': Reflections on a New Bible Commentary," Commentary 115, no. 4 (April 2003), 37-43.

7 W. Gunther Plaut and David E. S. Stein, The Torah: A Modern Commentary (New York: Union for Reform Judaism, 2005).

8 Tamara Cohn Eskenazi, The Torah: A Women's Commentary (New York: URJ Press and Women of Reform Judaism, 2008). 
could awake to a platform of daily Jewish text not limited to Talmud — and to Jewish media not limited to text." 9

\section{The Search for Ethical Teachings}

Many contemporary Jews study Torah or other classical texts not for mastery of the subject or coverage of a corpus, but rather, in order to seek guidance in living their lives, and wisdom about how to do so well. The Pew Research Center's 2013 Survey of American Jews indicated that, for those in the large sample, "Leading an ethical and moral life," along with remembering the Holocaust, were the most essential elements in "being Jewish." ${ }^{10}$ Where some might turn to self-help literature, others turn to the Jewish tradition. Torah study for adults, premised on discussion, argument, and example, can play an important role in building that ethical consciousness, especially when specifically oriented toward that function. As Rabbi David Teutsch recently reminded us:

The purpose of studying Torah is to gain insight and wisdom about how to lead a good life. While all forms of learning are laudable, the kind that qualifies as Torah study aims not primarily at increased knowledge or analysis, but at deeper understanding and deeper devotion to living out a commitment to goodness and authenticity. ${ }^{11}$

Torah study to guide decision-making can have a powerful appeal and a spiritual dimension. But there is also a literature, captured in the Mussar (selfdiscipline, moral conduct) movement, that argues that Torah is not enough, and that valuable ethical and spiritual guidance can be found in the last thousand years of medieval and rabbinic writings, from Ibn Gabirol and Maimonides to Chaim Luzzatto. Mussar was introduced in eighteenth century Lithuanian traditionalist yeshivot by Israel Salanter, a significant figure in the emergence of modern Jewish psychology and philosophy. Reform and Conservative scholars

9 Arnold M. Eisen, “A New Page for Jewish Learning," Wall Street Journal, August 9, 2012, http://www.wsj.com/articles/SB10000872396390443404004577578960721021888.

10 Pew Research Center, "A Portrait of Jewish Americans" (2013), 56, http://www.pewforum. org/files/2013/10/jewish-american-full-report-for-web.pdf.

11 David A. Teutsch, A Guide to Jewish Practice Vol. I: Everyday Living (Wyncote, PA: RRC Press, 2011), 70. Rabbi David A. Teutsch is the Wiener Professor of Contemporary Jewish Civilization and director of the Levin-Lieber Program in Jewish Ethics at the Reconstructionist Rabbinical College (RRC) in Philadelphia. He served for more than a decade as President of the RRC. 
and educators after the Second World War assumed leadership in spreading the program of study. ${ }^{12}$ Mussar introduced a now familiar set of Jewish valueshumility, generosity, kindness, thankfulness, order, empathy, holiness, community, and others - as the object of study, meditation, and practice. The most visible contemporary leaders among the non-orthodox are Alan Morinis and Ira F. Stone. ${ }^{13}$

\section{Books and Film}

Thus, while it is still the case that a majority of liberal American Jewish adults do not engage in anything that resembles text study, an impressive minority do so, through one or more of the avenues delineated here. Far from being a relic of a traditionalist society with uncritical assumptions about the meaning of the texts in question, something that we can identify as "text study" is alive and well in modern (liberal) Jewish America. This is fascinating, and it is deserving of both further study and further development.

At the same time, it is also worth calling attention to a complementary cultural phenomenon, the ways in which Jews engaged in consuming, discussing, and exploring other kinds of texts and text-analogues. Jews read all sorts of contemporary literature, and they like to talk about what they are reading. Novels, histories, memoirs, short stories, and poetry are all the focus of group study in a myriad of book clubs. "Jewish book clubs" as a Google query produced almost ten million hits, compared to three million hits for "African American book clubs," two million for Presbyterian, and under two million for Catholic. ${ }^{14}$ The places where the clubs convene are more likely to be homes

12 See Geoffrey Claussen, "The American Jewish Revival of Musar," The Hedgehog Review: Critical Reflections on Contemporary Culture 12, no. 2 (2010), http://iasc-culture.org/THR/ THR_article_2010_Summer_Claussen.php; Corinne E. Blackmer, "Transforming Ethical Behavior: The Musar Movement and the Care of the Self," Judaica Ukrainica 3 (2014), 24-36.

13 Alan Morinis is Dean of the Mussar Institute, which he founded more than a decade ago. He is the author of Climbing Jacob's Ladder: One Man's Journey to Discovery of a Jewish Spiritual Tradition (New York, Broadway Boosk, 2002), Everyday Holiness: The Jewish Spiritual Path of Mussar (Boston: Trumpeter, 2007), and Every Day, Holy Day (Boston: Trumpeter, 2010). See www.mussarinstitute.org for his online guidance of individual, havruta and group study. Rabbi Ira F. Stone has been working to strengthen Mussar practice within the Conservative movement. He is the author of A Responsible Life: The Spiritual Path of Mussar (Eugene, OR: Wipf and Stock Publishers, 2005).

14 On June 11, 2015, a Google query produced 9,830,000 hits for Jewish book clubs, 2,850,000 for African American, 2,180,000 results for Presbyterian, and 1,700,000 for Catholic book clubs. 
than congregations or community centers. The web is an important source for book titles, discussion guides, interviews with authors, and blogs about books. The interrogatory style, the questioning habits of mind, and the delight in argument, cultivated in Torah text study, are all in play when Jewish book clubs meet, although for many it can be mainly a social occasion.

The wide reach of Jewish book clubs, and the discussions they generate, are a prime example of how some of the methods used in the study of sacred text can be applied to novels, biographies, and memoirs. Book clubs help to build up knowledge of history, leadership, immigration, Zionism, gender roles, and cultural conflicts that is relevant for American Jews in the open society in which they live.

Film is recognized as a special kind of "text" by literary and media critics, ${ }^{15}$ and it has evolved over the past century under the guiding hand of Jewish producers whose names are now legends. Neal Gabler's An Empire of their Own (1988), ${ }^{16}$ tells that story. There is now a contagion to film festivals that celebrate Jewish themes and producers from around the world. According to a film reviewer in The Forward, eighty Jewish film festivals were scheduled in fifty states in 2014. The list of the twenty best included Baton Rouge, Charlotte, and Mobile, as well as New York, Miami, and San Francisco. The eleven-day JFilm festival in Pittsburgh has run for over twenty years, and a recent version included twenty films, twenty-eight screenings, and about four thousand attendees. ${ }^{17}$ Films have provided American Jews perspectives on the Holocaust, Israeli life, and diaspora conditions that they would otherwise be denied, and have extended considerably the sense of Jewish family and community.

\section{The Changing Face of Education: From Recitation to Structured Text Discussion}

Throughout this chapter, we are oscillating between highlighting the centrality of text study to Jewish community and acknowledging that text study is a

15 Stanley Fish made a significant contribution to reader-response theory and the practice of interpretive reading. See Fish, Is There a Text in This Class? The Authority of Interpretive Communities (Cambridge, MA: Harvard University Press, 1980).

16 Neal Gabler, An Empire of Their Own: How the Jews Invented Hollywood (New York: Crown, 1988).

17 See Sheerly Avni, “The Best Jewish Film Festivals of 2014,” The Forward, January 3, 2014 http://forward.com/culture/190088/the-best-jewish-film-festivals-of-2014/. For information about JFilm in Pittsburgh, see http://jfilmpgh.org/programs-events/festivals/jfilmfestival/. 
practice that is pursued by only a minority of the liberal Jewish community. We might wonder why the latter is the case. There are surely many reasons, but we want to call attention to one reason in particular that we believe has been underappreciated. The reason is this: Text study for children diminished in Reform and Conservative religious education over decades of trying to bring Jewish education into closer alignment with the formalized patterns of American education. Classroom discussion, until recently, was not an active part of American classroom practice. There was no recognized place for structured text-based discussions, discussions in which students were guided through — and had the opportunity to practice - rigorous consideration of problems, data, or written texts. On the contrary, the model that dominated formal American education was an information-delivery model. The textbook reigned supreme, with an authority that could not be questioned. It is no surprise that Jewish religious education mimicked the norms of general American education. A good Jewish religious educational environment was a classroom with a textbook (about Jewish history or thought or practice) from which the teacher could instruct and from which the students could absorb information.

Now, however, the tide has turned. In secular education, there is growing understanding of the limitations of textbooks, and growing interest in learning through active discussions of texts broadly considered. Interest in dialogic discussion-based methods of teaching and learning began in US lay education in the 1960s and 1970s and has grown since to become a major theme of scholarly research and applied education efforts. At the base of the new methods are theories of language as communication rooted in specific cultural traditions and of reading as an interpretive undertaking. Science and mathematics in this vein became reasoned argumentation rather than a collection of facts and procedures.

This nascent scholarly movement was already in process when a major compilation of the work of Lev Vygotsky (1896-1934), a Russian-Jewish educator and scholar of language and thinking, appeared in an English translation in $1978 .^{18}$ Vygotsky put forth a theory of language and intelligence as inherently social constructions. His work reached America just as the explosion of research on language, often collaborations between linguists and anthropologists, provided a stream of publications documenting the different ways that

18 See L. S. Vygotsky, Mind in Society: The Development of Higher Psychological Processes, ed. Michael Cole et al. (Cambridge, MA: Harvard University Press, 1978). An earlier translated compilation of his work, published in 1962, did not have the same impact. 
mostly oral language functioned in home, community, and school settings. In virtually all of these studies a marked difference in language between lower class and minority families and those of the ascendant groups was noted. Almost everyone observed that children from working or minority populations confronted language in school that was very different from that used at home. Yet, evidence mounted that certain kinds of classroom discussion could draw out significant reasoning abilities among even the poorest and most culturally isolated students.

Educators, and some political activists, gradually seized on these ideas as a way of simultaneously increasing the overall level of learning in American schools and, at the same time, the power of the schools to provide more equitable results across different populations of students. These were both important education agendas in the 1980's and '90s, furthered by publication of A Nation at Risk (1983) ${ }^{19}$ and the growing centrality of educational opportunity to the civil rights movement. The suggestions emerging from research on student discussion of problems or texts became more relevant to educators. In secular education, there was growing understanding of the limitations of textbooks and a rising interest in learning through active, teacher-guided but "student-owned" discussions.

Teacher-guided student discussions of literary texts (in English class and sometimes history), concepts and problems (in mathematics), and data sets (in science) are now among the most heavily promoted and researched practices in the learning sciences. This is true in North America and Western Europe especially, but to some extent in any part of the world that is investing in education. Academic conferences and teacher development workshops are likely to include multiple sessions on revising classroom practice to include much more discussion and argumentation.

Dialogic forms of teaching have theoretical roots in cognitive psychology, linguistics, child development, and social theories of mind. As teaching methods, they may be called Accountable Talk, Academically Productive Talk, argumentation, or several other titles. ${ }^{20}$ Because of the way it features

19 National Commission on Excellence in Education, A Nation at Risk: The Imperative for Educational Reform (US Department of Education: 1983).

20 Lauren B. Resnick et al., "How (Well-Structured) Talk Builds the Mind," in Innovations in Educational Psychology: Perspectives on Learning, Teaching, and Human Development, ed. David D. Preiss and Robert J. Sternberg (New York: Springer, 2010), 163-94. Accountable Talk is a registered trademark of the University of Pittsburgh. Lee Shulman has made his own case for accountability in pedagogy: "A persistent problem of most forms of education 
argumentation and philosophical reasoning, Matthew Lipman's Philosophy for Children, introduced to American schools in the 1970s, belongs with this group of discussion-rich pedagogies. It is worth looking in depth at this form of talk-what it is and what it is not-because of its similarities to the Jewish critical approach to text.

In this still small but rapidly growing field of research, almost everyone agrees on three points about effective classroom talk. Each has a reasonably strong body of supporting research evidence, much of it now assembled in a volume published by the American Education Research Association (2015) based on a conference held in Pittsburgh. ${ }^{21}$

1. The talk is argumentative, sometimes noisily so, as children struggle to express ideas that are new to them, outside of their "comfort zone."

2. It is teacher-structured, but student-owned. Teachers set problems and "standards" for debating them, but students develop the ideas, "turning them and turning them again" in an echo of Jewish religious text study.

3. There are clear standards for what counts as a good discussion, often described as the "three accountabilities:" accountability to knowledge, getting the "facts" right even if it is a struggle to find exactly the right wording; accountability to reasoning, being able to provide a rational justification for a claim or explanation; accountability to community, speaking in ways that respect the ideas and feelings of other students.

In this form of talk, students think out loud: noticing something about a problem, puzzling through a surprising finding, or articulating, explaining, and reflecting upon their own reasoning. The teacher works to elicit a range of ideas, which may be emergent or incomplete. With teacher guidance, other students take up their classmates' statements: building on, challenging, or clarifying a claim (including a teacher's claim); posing questions; reasoning about a proposed solution; or offering a counter claim or an alternate explanation.

is that they permit student invisibility, which breeds disinterest and leads to zoning out and non-learning. Learning requires that students feel visible and accountable." See Lee Shulman, "Pedagogies of Uncertainty," Liberal Education 91, no. 2 (2005), 18-25.

21 See Lauren B. Resnick et al., eds., Socializing Intelligence Through Academic Talk and Dialogue (Washington, DC: American Educational Research Association, 2015). Contributors to thirty-four chapters present our current understanding of the theory, practice, and effectiveness of discussion teaching in different forms, disciplines, and countries. 
All students are positioned as intellectual agents in the discussion; all students are expected to use their minds. Overall, the teacher's goal is to sustain a process of shared reasoning that ultimately leads to a more fully developed, evidence-backed conclusion, solution, or explanation.

These forms of dialogic teaching and learning are quite different from the traditional American and European traditions of recitation that migrated out of Christian religious training into lay schools in many countries beginning in the eighteenth century. The school-based version of recitation is widely used to teach a defined body of knowledge to students who may be only weakly literate and in any case are expected to learn only simple ideas. Although such exchanges may sometimes probe for meaning, there is little of the intellectual challenge that characterizes lively Torah study. Correct answers are sought, without aiming for deep understanding. Unfortunately, this recitation model is still widely used in American classrooms, although it is under challenge for reasons we have indicated.

The key difference between recitation and dialogic learning lies in who owns the storyline-who is allowed to change it. In Accountable Talk, teachers do not merely repeat what students say, they ask students whether their own "re-voicing" faithfully captured the student's intended meaning. A teacher might say, "I'm not sure I understand. Did you mean. . .?" or "I'm not sure I have your thinking right. Are you saying. . .?" These moves not only engage students in co-constructing an argument, they reinforce for students that they "own" their own ideas, that they have minds that can change and grow. Decades of research have shown that students who believe that the mind can grow are more successful academically than those who see intelligence as fixed.

\section{Bridging Jewish Text Study and Contemporary Dialogic Education}

Accountable Talk and other forms of dialogic education share some features with havruta, a form of paired text study considered a signature Jewish pedagogy. Havruta has been documented and analyzed in orthodox yeshivas by Baruch Schwarz and in a non-orthodox after-school program by Orit Kent. ${ }^{22}$

22 See Baruch B. Schwarz, "Discussing Argumentative Texts as a Traditional Jewish Learning Practice," in Resnick, Socializing Intelligence, 157-66, as well as his chapter in this volume. Eli Holzer and Orit Kent describe methods and concepts in A Philosophy of Havruta: Understanding and Teaching the Art of Text Study in Pairs, Jewish Identities in PostModern Society (Boston: Academic Studies Press, 2013). See also Orit Kent, "A Theory of Havruta Learning," in Turn It and Turn It Again: Studies in the Teaching and Learning of 
In both havruta settings, pairs of students are co-constructing the meaning of texts. They agree and disagree, negotiate rewordings, and look for resources within the assembled texts to support their interpretations or challenge those of their partners. When they can't resolve their disagreements they ask for help. This process allows students to make decisions or enlarge their interpretive options.

Kent has worked with both teachers and students. Her pilot with middle school students has some unique features. Students follow guidelines. They use note cards to prompt attention to listening, paraphrasing (re-voicing), attending to the evidence, and dealing with different interpretations. In her model, the text is assumed to have a voice in the discussions, several pairs are at work in the same classroom, and the teacher is present to guide the work of the pairs when needed. ${ }^{23}$

The interpenetration of traditional Jewish approaches to text and modern literary approaches to reading and discussion can also be seen in Shira Horowitz's description of how she has taught the weekly Torah portion to young children. Her sessions of "Torah talk" begin to structure, for those who are only six and seven years old, the features of Torah study for more mature children and adults. Incorporating the work of Lucy Calkins ${ }^{24}$ on reading instruction for children, she has had her students ask questions, attend to what is in the text, listen to one another, paraphrase, summarize, and find their own voice. Even very young children can develop an appreciation for the interplay of reader and text.

These examples demonstrate an impressive degree of coherence between the central aspects of contemporary dialogic education and the features of traditional Jewish text study, even when that text study is carried out in notexactly-traditional settings. But we believe that there are further, untapped opportunities to bridge Jewish text study and dialogic education.

Classical Texts, eds. Jon A. Levisohn and Susan P. Fendrick (Boston: Academic Studies Press, 2013), 286-322.

23 For an excellent video presentation of how this works in the classroom, see Allison Cook and Orit Kent, "Learning Torah Through Partnership (9.5-minute version," Mandel Center for Studies in Jewish Education, 2014, as well as their accompanying viewer's guide, found at http://www.brandeis.edu/mandel/pdfs/2014-10-24_Video-companion_Learning_Torah_ through_Partnership.pdf. See also Orit Kent and Allison Cook, "Leveraging Resources for Learning Through the Power of Partnership," Working Paper (Beit Midrash Research Center, Jack, Joseph and Morton Mandel Center for Studies in Jewish Education, Brandeis University, 2014).

24 For more on Lucy Calkins and the Writing Workshop, see her background, publications, and interests in http://www.tc.columbia.edu/academics/index.htm?facid=lmc71. 
One example may be the kinds of Jewish book clubs or discussion groups to which we referred earlier. Within these groups, leaders and participants benefit from discussion questions, often included in published works. The online National Jewish Book Club offers its own set of questions for selected titles, along with other aids to facilitate discussion. ${ }^{25}$ But discussion questions alone are not sufficient to structure the kind of genuinely dialogic environment that we would like to see. To be sure, many skilled facilitators intuit on their own how to make a comfortable space for textual exploration. But others need help. They need guidance about how to structure dialogue in ways that will empower the discussants and yet respect the text. The "three accountabilities" of Accountable Talk would certainly reduce the conversational wanderings that threaten poorly guided discussions. There is an art, we know from our Jewish tradition, to productive discussion of text. Articulating the desired norms and making them easily comprehensible would go a long way to enriching this setting for the study of texts.

Here it is also important to note that just as digital technology has helped to widen and deepen for more readers the discussion of sacred text, so has it also changed discussions of other Jewish writings. Before a book club meeting, many attendees have had access to reviews, accessed online. And once the discussion begins, if they have their book in tablet form, they can challenge one another by referring easily to specific passages, searching for phrases, or even doing word counts. In other words, it is now easier for more readers to argue from the text. When we envision Jewish book groups as sites for dialogic textual investigation, we should actively integrate the technology at our fingertips to help make readers more active in establishing meaning and owning an interpretation.

This is one example of a way of deepening and enriching text study within Jewish communities. Are there others? Surely there are-but we may need to adopt a more experimental approach than we are used to. One aspect of an experimental approach is to seek out "natural experiments," undertaken without design or oversight, responding to local needs. Where is text study flourishing? Who has undertaken a novel approach? These natural experiments can and must be documented and analyzed, generating a knowledge base for others. Beyond the naturally occurring experiments, however, a

25 Among the many Jewish book clubs, The National Jewish Book Club stands out for the quality of its offering and the many study aids. See http://www.jewishbookcouncil.org/ bookclub/national-jewish-book-club. For the Yale UP Jewish biography series, see http:// www.jewishlives.org/ 
second aspect of an experimental approach is more intentional innovation, undertaken with the express purpose of trying out new methods and documenting the process. We suggest, therefore, a project that attempts to explore text study in a series of learning experiments, conducted in pilot form in a small number of communities.

Skilled educators have an opportunity to devise short courses, outdoor experiences, and one-off experiences that enlarge the opportunity for discussion of texts. Adults and young people might study together or separately. The groups may be guided by rabbis and other trained educators or by lay members willing to put in time to learn the texts and available resources in depth. The texts studied might follow the traditional Jewish calendar of study, or a study group may choose texts that explore certain ethical themes. The study groups may meet in synagogues or other specifically Jewish spaces, or in countryside campgrounds, retreat settings, or homes. We can experiment with calendars that will make the experience maximally available to those who would like to participate. We imagine a spreading leadership — with new groups being formed as new interests are recognized.

Eventually, presumably, there will need to be some reliable funding streams to grow these experimental study programs and provide study materials that help people access the ideas-traditional and new-that study will itself produce. But the program in any given city could begin with almost no funding at all — meeting in homes and synagogues and using study materials that are easily available on the web.

Maintaining, extending, and deepening the study of texts of all kinds at all ages is a challenge for congregations, community centers, Jewish media, and inter-denominational collaboration. The potential for exciting text study experiences, however, is substantial, even for school-age children who find schoolbased study "boring." We can see how animated children become when engaged in close analysis and discussion of texts. This is true for text study in secular classrooms as well as for the study of Jewish texts in Jewish learning environments. Those who seek "a renewal of spirit" may find that it begins in the pedagogy of small-group learning in school programs, summer camps, and retreats.

In many ways what we are proposing is something so old - for the Jewsthat we wonder whether we need to propose it. Maybe it is happening already. If so, our main task will be to discover it, document it, promote it, enlarge it, make it so exciting that everyone is talking about the study of texts as a central feature of Jewish communal life. 


\title{
Conclusion
}

We expect widening expressions of Jewish cultural life, extending within and beyond currently recognized venues. Each of us has in our home the power to call up the great library of Alexandria, the galleries of the Louvre, and the latest expressions of stand-up Jewish comedy. With our digital devices, we can also create rallies for worthy causes, protest injustice, support the needy, and explore the relationship of religious communities and the state. The world appears to be unfolding before us.

Learning and study have a central place in this expansion of Jewish life. We have continued to explore our Torah, in all its dimensions. In the words of Rabbi David Teutsch:

\begin{abstract}
Torah study is not limited to Bible, midrash and Talmud. It can include medieval Jewish philosophy and poetry, kabbala (medieval Jewish mysticism) and hasidut (the works of Hasidism) ... contemporary thought and so on. Many of us would include works by Jewish and non-Jewish artists, writers and spiritual masters as well. ${ }^{26}$
\end{abstract}

Our sages established study, prayer, and good deeds as the foundation of a Jewish life, but they did not place limits on where to pray, fix the boundaries of what to study, or circumscribe where we would perform our acts of kindness. We have respected life as a continuing creation, and acknowledged our responsibility to invent and adapt, even as we celebrate our tradition. There is an amazing fullness to the variety of Jewish life in North America.

We believe that the growing interest in Jewish study of all kinds will find a locus in homes, community centers, movie theatres, camps, and places we cannot now imagine. As it grows, more adults and families will enjoy discussion and argument around texts of all kinds. The focus on study has brought many benefits to American Jews in family life, daily habits, and educational goals. It has extended the Jewish presence and influence in the professions and the broader society. Maintaining a heritage, however, requires practice.

We have seen that traditional Jewish learning methods (for both children and adults) share many features with the styles of Accountable Talk and other forms of dialogic education that are emerging in general education: discussion of texts; commitment to a "knowledge based" form of reasoning and argumentation; and willingness to approach difficult topics. It is time to harvest these learning techniques across boundaries of age and denomination.

26 Teutsch, A Guide to Jewish Practice Vol. I, 70. 


\section{Bibliography}

"A Portrait of Jewish Americans." Pew Research Center, 2013. http://www.jewishdatabank.org/ studies/downloadFile.cfm?FileID=3088.

Avni, Sheerly. “The Best Jewish Film Festivals of 2014.” The Forward, January 3, 2014. h t t p : / / forward.com/culture/190088/the-best-jewish-film-festivals-of-2014/.

Blackmer, Corinne E. "Transforming Ethical Behavior: The Musar Movement and the Care of the Self." Judaica Ukrainica 3 (2014). http://judaicaukrainica.ukma.edu.ua/ckfinder/userfiles/files/JU_3_2013_Blackmer.pdf.

“Calkins, Lucy." Teachers College: Columbia University. http://www.tc.columbia.edu/faculty/ $\operatorname{lmc} 71 /$.

Claussen, Geoffrey. "The American Jewish Revival of Musar." The Hedgehog Review: Critical Reflections on Contemporary Culture 12, no. 2 (2010). http://iasc-culture.org/THR/THR_ article_2010_Summer_Claussen.php.

Cohn Eskenazi, Tamara. The Torah: A Women's Commentary. URJ Press and Women of Reform Judaism, 2008.

Cook, Allison, and Orit Kent. "Learning Torah through Partnership' A Viewer's Guide." Mandel Center for Studies in Jewish Education, 2014. http://www.brandeis.edu/mandel/ pdfs/2014-10-24_Video-companion_Learning_Torah_through_Partnership.pdf.

"Learning Torah Through Partnership (9.5 minute version)." Mandel Center for Studies in Jewish Education, 2014. https://vimeo.com/97982899.

Eisen, Arnold M. “A New Page for Jewish Learning." The Wall Street Journal, August 9, 2012. https://www.wsj.com/articles/SB10000872396390443404004577578960721021888.

Fish, Stanley. Is There a Text in This Class? The Authority of Interpretive Communities. Cambridge, MA: Harvard University Press, 1980.

Gabler, Neal. An Empire of Their Own: How the Jews Invented Hollywood. New York: Crown, 1988.

Goldstein, Andrew. "Annual Shavuot Study Draws Hundreds." The Jewish Chronicle, 2013. http://thejewishchronicle.net/pages/full_story/push?article-Annual+Shavuot+study+draws+hundreds\%20\&id $=22681762$.

"Jewish Pittsburgh Studies All Night and Into the Morning to Mark Shavuot." The Jewish Chronicle, 2012. http://www.thejewishchronicle.net/view/full_story/18843574/ article-Jewish-Pittsburgh-studies-all-night-and-into-the-morning-to-mark-Shavuot. 
Halkin, Hillel. "'Boiling a Kid': Reflections on a New Bible Commentary." Commentary 115, no. 4 (April 2003), 37-43.

Holtz, Barry W., ed. Back to The Sources: Reading the Classic Jewish Texts. New York: Summit Books, 1984.

Holzer, Eli, and Orit Kent. A Philosophy of Havruta: Understanding and Teaching the Art of Text Study in Pairs. Jewish Identities in Post-Modern Society. Boston: Academic Studies Press, 2013. "Jewish Lives: Biographies that Illuminate Jewish Experience." JewishLives.org. https://www. jewishlives.org/.

JFilm Festivals Pittsburgh. http://filmpittsburgh.org/.

Kent, Orit. "A Theory of Havruta Learning." In Turn It and Turn It Again: Studies in the Teaching and Learning of Classical Texts. Edited by Jon A. Levisohn and Susan P. Fendrick. Boston: Academic Studies Press, 2013.

Kent, Orit, and Allison Cook. "Leveraging Resources for Learning Through the Power of Partnership." Working Paper. Beit Midrash Research Center, Jack, Joseph and Morton Mandel Center for Studies in Jewish Education, Brandeis University, 2014.

Kotler-Berkowitz, Laurence, Steven M. Cohen, Vivian Klaff, Frank Mott, Lorraine Blass, Jim Schwartz, Jonathan Ament. "National Jewish Population Survey (NJPS) 2000-01." United Jewish Communities, 2001. http://www.jewishdatabank.org/studies/details.cfm?StudyID=307.

Lieber, David L. Etz Hayim: Torah and Commentary. Philadelphia: Jewish Publication Society, 2001.

Lisa Grant. "Jewish Men and Adult Jewish Learning." In The Gender Gap: A Congregational Guide for Beginning the Conversation about Men's Involvement in Synagogue Life. Edited by Hara E. Person with Carolyn Bricklen, Owen Gotlieb, and Melissa Zalkin Stollman. New York: URJ Press 2007. http://www.bjpa.org/Publications/downloadFile.cfm?FileID=4701.

Morinis, Alan. Climbing Jacob's Ladder: One Man's Rediscovery of a Jewish Spiritual Tradition. Broadway Books: 2002.

Every Day, Holy Day: 365 Days of Teachings and Practices from the Jewish Tradition of Mussar. Shambhala: 2010.

Everyday Holiness: The Jewish Spiritual Path of Mussar. Shambhala: 2007.

National Commission on Excellence in Education. A Nation at Risk: The Imperative for Educational Reform. US Department of Education: 1983.

“National Jewish Book Club." Jewish Book Council. http://www.jewishbookcouncil.org/bookclub/national-jewish-book-club.

Oz, Amos, and Fania Oz-Salzberger. Jews and Words. New Haven, CT: Yale University Press, 2012.

Plaut, W. Gunther, and David E. S. Stein. The Torah: A Modern Commentary. Union for Reform Judaism, 2005.

Resnick, Lauren B., Christa S. C. Asterhan, and Sherice N. Clarke, eds. Socializing Intelligence Through Academic Talk and Dialogue. Washington, DC: American Educational Research Association, 2015. 
Resnick, Lauren B., Sarah Michaels, and M. C. O’Connor. "How (Well-Structured) Talk Builds the Mind." In Innovations in Educational Psychology: Perspectives on Learning, Teaching, and Human Development. Edited by David D. Preiss and Robert J. Sternberg. New York: Springer, 2010.

Schorsch, Ismar. Forward to Etz Hayim: Torah and Commentary. Edited by David L. Lieber. Philadelphia: Jewish Publication Society, 2001.

Schwarz, Baruch B. "Discussing Argumentative Texts as a Traditional Jewish Learning Practice." In Socializing Intelligence Through Academic Talk and Dialogue. Edited by Lauren B. Resnick, Christa S. C. Asterhan, and Sherice N. Clarke. Washington, DC: American Educational Research Association, 2015.

Shulman, Lee S. "Pedagogies of Uncertainty." Liberal Education 91, no. 2 (2005).

Stone, Ira F. A Responsible Life: The Spiritual Path of Mussar. Eugene, OR: Wipf and Stock Publishers, 2005.

Tabachnick, Toby. "Community Shabbaton Will Cross Denominational Lines." The Jewish Chronicle, 2012. http://thejewishchronicle.net/view/full_story/18356336/article-Community-Shabbaton-will-cross-denominational-lines.

Teutsch, David A. A Guide to Jewish Practice Vol. I: Everyday Living. Wyncote, PA: RRC Press, 2011.

Ukeles Associates. “The 2002 Pittsburgh Jewish Community Study Final Report.” United Jewish Federation of Greater Pittsburgh and Jewish Healthcare Foundation, December 2002, revised. http://www.jfedpgh.org/document.doc?id=13.

Vygotsky, L. S. Mind in Society: The Development of Higher Psychological Processes. Edited by Michael Cole, Vera John-Steiner, Sylvia Scribner, and Ellen Souberman. Cambridge, MA: Harvard University Press, 1978. 
